\title{
Floristic and Vegetation Study on the Main Weed Communities Associated with Wheat (Triticum aestivum L.) Crop
}

\author{
Ahmed A. Khalafallah ${ }^{1}$, Tarek M. Galal ${ }^{2}$, Mona Naim ${ }^{1}$, Manar A. Soliman ${ }^{1 *}$ \\ ${ }^{1}$ Botany Department, Faculty of Women for Art, Science and Education, Ain-Shams University \\ ${ }^{2}$ Botany and Microbiology Department, Faculty of Science, Helwan University
}

\begin{abstract}
The present study aims at studying the floristic features and community types of the main weed species associated with wheat crop in Menofia Province, Egypt. Sixty stands (each $10 \times 10 \mathrm{~m}$ ) were randomly selected in five wheat farms for monthly determining the cover of weed species along the growing season of wheat. Twenty nine species belonging to 28 genera and 17 families were recorded associated with wheat crop. The most dominant families were Poaceae, Brassicaceae and Fabaceae. Annual weeds were represented by 26 species, while perennials were 3 species. Therophytes were the dominant life form (26 species), while geophytes-helophytes, chamaephytes and hemicryptophytes were represented by on species (Cyperus rotundus, Solanum nigrum and Convolvulus arvensis, respectively). The application of TWINSPAN on the cover estimates of 29 associated species recorded in the 60 sampled stands in wheat, led to the recognition of 8 vegetation groups: A: Convolvulus arvensis, $\mathbf{B}$ : Malva parviflora, C: Polypogon monspliensis, D: Capsella pursa-pastoris, E: Euphorbia peplus, F: Chenopodium murale, G: Sonchus oleraceous, and $\mathbf{H}$ : Beta vulgaris. M. parviflora group had the highest values of species richness and relative concentration of dominance, while C. murale group had the lowest values of species richness, relative evenness and relative concentration of dominance. Moreover, the highest value of relative evenness was recorded in M. parviflora and C. pursa-pastoris group. The present study is the keystone for further investigation on the weed function and weed management practices.
\end{abstract}

Key words: Wheat, assemblage, weeds, floristic, community types.

\section{Introduction}

Agriculture can be conceived as the management of terrestrial ecosystems to divert their productive capacity to serve human needs (Millennium Ecosystem Assessment, 2005). As such, agro-ecosystems provide benefits for humankind, i.e. "ecosystem services", mostly in the form of primary production such as food, feed, timbers, fibers and other natural

\footnotetext{
* Corresponding author. Manar_asm @yahoo.com
} 
products (Petit et al., 2011). Plant based food has played an important role in human nutrition, being a very important source of antioxidants, vitamins and minerals (Kulkarni et al., 2007).

A major objective of most weed community ecology studies has been to identify patterns of species composition and distribution and to interpret these patterns in relation to known or presumed gradients in the environment (Fried, 2008). Quantitative analysis, especially quantitative classification methods and ordination techniques, has been widely used to indicate the ecological relationships between vegetation and the environment (Zhang and Zhang, 2000). Moreover, floristic studies are not only important to know the variety of plants present in an area, but also socio-economically significant. They provide shelter, food, medicine and everything for the human being and other species of that area.

Weeds are plants which grow where they are not wanted. They differ from other plants in being more aggressive, having peculiar characteristics that make them more competitive (Gomaa, 2012). Weeds act as drivers of changes of ecosystem function, nutrients cycling, food webs, plant community structure, habitat availability for animals and fire regimes (Ghersa et al., 1996). They are considered one of the main factors limiting agricultural production systems (Petit et al., 2011; Radicetti et al., 2013). Yield losses due to weeds are a major cause of low yields in direct-seeded cereals systems and there is considerable scope to improve weed management (Johnson et al., 2004). Raising seedlings in a seed bed gives the cereal crop a competitive advantage over weeds and this has long been one of the main components of weed management in traditional cropping systems (Bastiaans et al., 2000).

Weeds are an integral component of agro-ecosystems and play an important role in diversifying of the land. Evidence from field experiments shows that weeds can be used to increase species diversity of an ecosystem, reduce pest density, and maintain soil fertility (Chen et al. 2004). One of the main problems that agricultural production faces is weeds that interfere with crop growth and production. These weeds compete with plant species for water, light, nutrients and space (Al-Johani et al. 2012). Fried (2009) reported that arable weed species play an important role in supporting biological diversity, in particular as food resources of primary importance for birds and insects inhabiting farmlands. Moreover, weed communities are affected by many factors as farm management practices, crop type, season and soil characteristics. Many factors involved in the formation of the weed community make 
it difficult to evaluate the relative importance of each individual factor (Shehata and Galal, 2015).

In farming systems, weeds are one of the major threats to crop production; however the risk of weeds is not only reducing the main crop yields, but also decreasing the commercial quality and the feeding palatability of main crops (Uchino et al., 2012). In addition, they increase the soil seed bank of weeds (Buhler, 1999), which may cause severe weed infestation in subsequent crop production (Uchino et al., 2009). Moreover, planting method is an important yield-contributing factor. Whereas, row spacing in planting method is very important for crop plants and it is determined by the growth habit of the crop and agroclimatic conditions (Devi et al., 1990). The present study aims at studying the floristic features and community types of the main weed species associated with wheat crop in Menofia Province, Egypt. This study is the keystone for further investigation on the weed function and weed management practices.

\section{Materials and Methods}

\subsection{Floristic analysis}

The weed flora associated with wheat crop was surveyed during the growth season (January - April, 2104). Sixty stands $(10 \times 10 \mathrm{~m})$, randomly selected in five wheat farms, and were observed monthly throughout the growing season. A list of weed species was made for each sampled stand. A visual estimate of the total cover and the cover of each weed species (\%) was assessed using Réléve method (Muller-Dombois and Ellenberg, 1974). Identification and nomenclature of weed species were according to Täckholm (1974), ElHadidi and Fayed (1994/1995) and Boulos (2009). Voucher specimens were deposited in Faculty of Women, Botany Department Herbarium and Helwan Faculty of Science (HCH) Herbarium.

Life forms of the recorded species were identified following the Raunkiaer scheme (Raunkiaer, 1937) as follows: Ch: chamaephytes, H: hemicryptophytes, GH: geophyteshelophytes, and Th: therophytes. The absolute and relative numbers of species belonging to each life form (biological spectrum) were calculated. In addition, the global geographical distribution of the recorded weed species was gathered from Täckholm (1974), Zohary (1966, 1972), Wickens (1977), and Ahmed (2003). The global distribution (i.e. floristic regions) is coded as follows: ME: Mediterranean, COSM: Cosmopolitan, SA-AR: SaharoArabian, Trop: Tropical, S-Z: Sudano-Zambezian, ER-SR: Euro-Siberian, IR-TR: IranoTuranian, PAL: Palaeotropical, and PAN: Pantropical. 


\subsection{Vegetation analysis}

Two-Way Indicator Species Analysis (TWINSPAN), as a classification technique and Detrended Correspondence Analysis (DCA), as an ordination technique were applied to the matrix of cover estimates of 29 weed species in 60 stands in wheat crop (Hill 1979a, b). Species richness (alpha-diversity) for each vegetation group was calculated as the average number of species per stand. Species turnover (beta-diversity) was calculated as a ratio between the total number of species recorded in a certain vegetation group and its alpha diversity (Whittaker, 1972). Relative evenness or equitability (Shannon-Wiener index) of the importance value of species was expressed as: $\hat{\mathrm{H}}=-\Sigma^{\mathrm{s}} \mathrm{Pi}(\log \mathrm{Pi})$, where $\mathrm{S}$ is the total number of species and $\mathrm{Pi}$ is the relative importance value (i.e. relative cover) of the species. The relative concentration of dominance is the second group of heterogeniety indices and is expressed by Simpson's index: $\mathrm{D}=1 / \mathrm{C}\left\{\mathrm{C}=\Sigma^{\mathrm{s}}(\mathrm{Pi})^{2}\right\}$, where $\mathrm{S}$ is the total number of species and $\mathrm{Pi}$ is the relative importance value (relative cover) of species. More details about these indices are available in Pielou (1975) and Magurran (1988).

\section{Results and Discussion}

\subsubsection{Floristic analysis}

The recorded species associated with wheat crop with their families, life forms and floristic categories are presented in Table 1. Twenty nine species belonging to 28 genera and 17 families were recorded associated with wheat crop. The most dominant families were Poaceae, Brassicaceae, Fabaceae (4 species for each), Chenopodiaceae (3 species), and Asteraceae (2 species), however the other families were represented by only one species (Fig. 1).

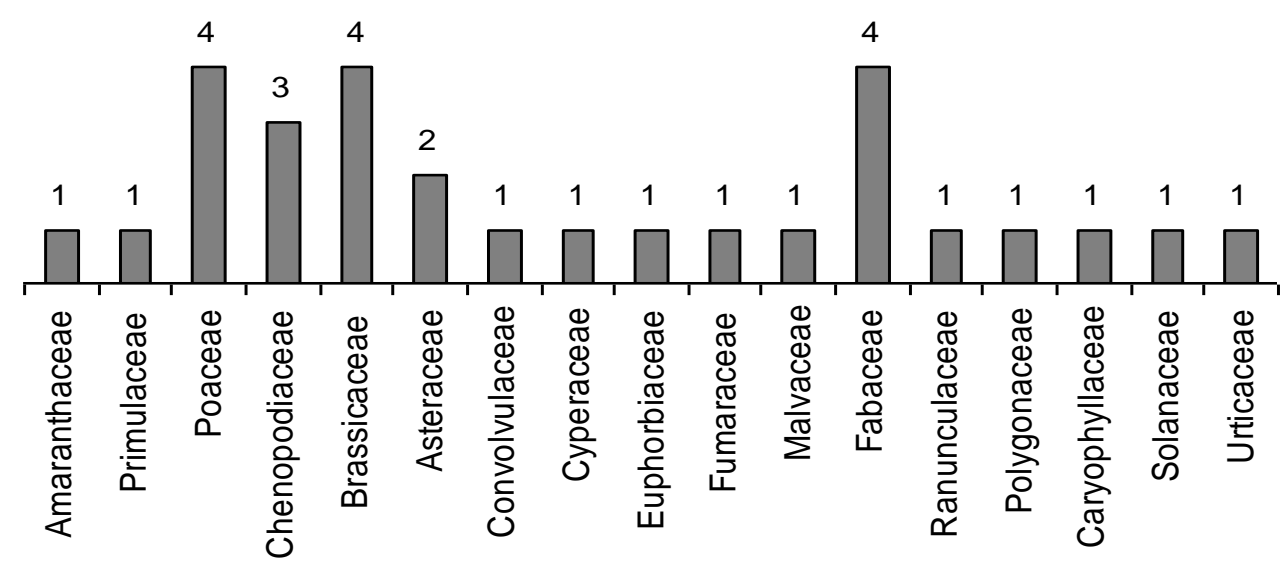

Families

Fig 1: Number of weed species belonging to the different families associated with wheat crop. 


\subsubsection{Habit of species}

The majority of weed species (26 species), associated with wheat crop, were annuals (e.g. A. hybridus, A. arvensis, A. fatua, B. vulgaris, C. bursa-pastoris, and $C$. muraleSetariaviridis), while perennial weeds were represented by three species (Table 1). The common annuals recorded in wheat farms were (Convolvulus arvensis, Cyperus rotundus and Solanum nigrum).

\subsubsection{Life forms}

The life form spectrum of the recorded species associated with wheat indicated the presence of four life forms: hemicryptophytes, geophytes-helophtes, chamaephytes and therophytes (Fig. 2). It was found that, therophytes were the dominant life form represented by 26 species associated with wheat, while geophytes-helophytes, chamaephytes and hemicryptophytes were represented by on species (C. rotundus, S. nigrum and C. arvensis, respectively).

Table 1. Floristic properties of the recorded species associated with wheat crop

\begin{tabular}{|c|c|c|c|c|c|}
\hline Species & Family & $\begin{array}{l}\text { Arabic } \\
\text { Name }\end{array}$ & Habit & $\begin{array}{l}\text { Life } \\
\text { form }\end{array}$ & Floristic category \\
\hline Amaranthus hybridus L. & Amaranthaceae & رعاف & Annual & Th & COSM \\
\hline Anagallis arvensis $\mathrm{L}$. & Primulaceae & عين القط & Annual & Th & ME+ER-SR+IR-TR \\
\hline Avena fatua $\mathrm{L}$. & Poaceae & زمير & Annual & Th & COSM \\
\hline Beta vulgaris $\mathrm{L}$. & Chenopodiaceae & 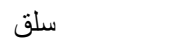 & Annual & Th & ME+ER-SR+IR-TR \\
\hline Brassica tournefortii Gouan & Brassicaceae & شرطام & Annual & Th & $\mathrm{ME}+\mathrm{SA}-\mathrm{AR}+\mathrm{IR}-\mathrm{TR}$ \\
\hline Capsella bursa-pastoris (L.) Medik. & Brassicaceae & 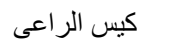 & Annual & Th & COSM \\
\hline Chenopodium ficifolium $\mathrm{Sm}$. & Chenopodiaceae & منتنه & Annual & Th & COSM \\
\hline Chenopodium murale $\mathrm{L}$. & Chenopodiaceae & 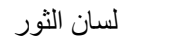 & Annual & $\mathrm{Th}$ & COSM \\
\hline Cichorium endivia $\mathrm{L}$. & Asteraceae & شيكوريا & Annual & Th & ME+IR-TR \\
\hline Convolvulus arvensis $\mathrm{L}$. & Convolvulaceae & عليق & Perennial & $\mathrm{H}$ & Trop \\
\hline $\begin{array}{l}\text { Coronopus niloticus (Delile) } \\
\text { Spreng. }\end{array}$ & Brassicaceae & حاره & Annual & Th & S-Z+EGYPT \\
\hline Cyperus rotundus $\mathrm{L}$. & Cyperaceae & سعد & Perennial & $\mathrm{GH}$ & ME+IR-TR+Trop \\
\hline Euophorbia peplis L. & Euphorbiaceae & لبينة & Annual & Th & $\mathrm{ME}+\mathrm{ER}-\mathrm{SR}+\mathrm{IR}-\mathrm{TR}$ \\
\hline Fumaria gaillardotii Boiss. & Fumaraceae & 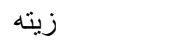 & Annual & Th & $\mathrm{ME}+\mathrm{ER}-\mathrm{SR}+\mathrm{IR}-\mathrm{TR}$ \\
\hline Hordeum vulgare $\mathrm{L}$. & Poaceae & 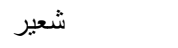 & Annual & $\mathrm{Th}$ & ME+IR-TR \\
\hline Malva parviflora $\mathrm{L}$. & Malvaceae & 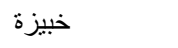 & Annual & $\mathrm{Th}$ & ME+IR-TR \\
\hline Medicago polymorpha $\mathrm{L}$. & Fabaceae & نفل ل & Annual & Th & COSM \\
\hline Phaseolus vulgaris $L$. & Fabaceae & فاصوليا & Annual & Th & Cultivated \\
\hline Pisum sativumL. & Fabaceae & بسلة بلة & Annual & Th & Cultivated \\
\hline Poa anпua $\mathrm{L}$. & Poaceae & سبل أبو الحسين & Annual & Th & ME+ER-SR+IR-TR \\
\hline Polypogon monspeliensis (L.) Desf. & Poaceae & ديل القط & Annual & Th & COSM \\
\hline Ranunculus sceleratus $\mathrm{L}$. & Ranunculaceae & ز غلنتة & Annual & Th & $\mathrm{ME}+\mathrm{ER}-\mathrm{SR}+\mathrm{IR}-\mathrm{TR}$ \\
\hline Raphanus sativus $\mathrm{L}$. & Brassicaceae & 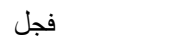 & Annual & Th & Cultivated \\
\hline Rumex dentatus $\mathrm{L}$. & Polygonaceae & حميض & Annual & $\mathrm{Th}$ & ME+ER-SR+IR-TR \\
\hline Silene rubella $\mathrm{L}$. & Caryophyllaceae & أبو النجف & Annual & Th & ME \\
\hline Solanum nigrum $\mathrm{L}$. & Solanaceae & عنب الديب & Perennial & $\mathrm{Ch}$ & ME+ER-SR+IR-TR \\
\hline Soncuhs oleraceous L. & Asteraceae & جعضيض & Annual & Th & COSM \\
\hline Trifolium alexandrinum $\mathrm{L}$. & Fabaceae & برسيم & Annual & Th & ME \\
\hline Urtica urens $\mathrm{L}$. & Urticaceae & 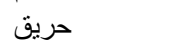 & Annual & Th & ME+ER-SR \\
\hline
\end{tabular}




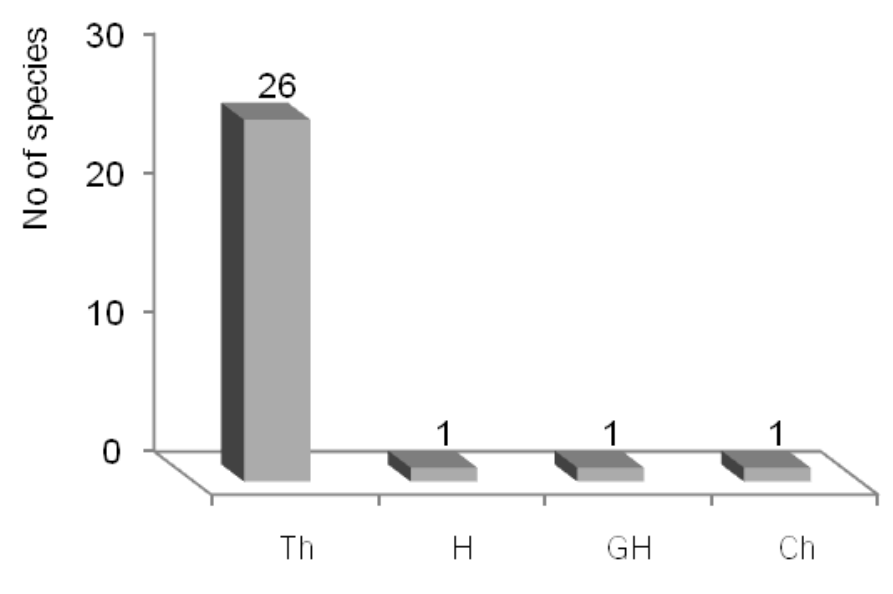

Fig. 2. Life form spectra of the recorded associated species in each of the wheat crop.Th: therophytes. $\mathrm{H}$ : hemicryptophytes, $\mathrm{GH}$ : geophyte - helophytes and $\mathrm{Ch}$ : chamaephytes.

\subsubsection{Chorological analysis}

The spectrum of the global distribution of the recorded species associated with wheat crop indicated that pluri-regional taxa were the dominant elements in wheat farms; represented by 10 species, followed by cosmopolitans ( 8 species), bi-regionals ( 5 species) and monoregional elements, which were represented by three species (Fig. 3).

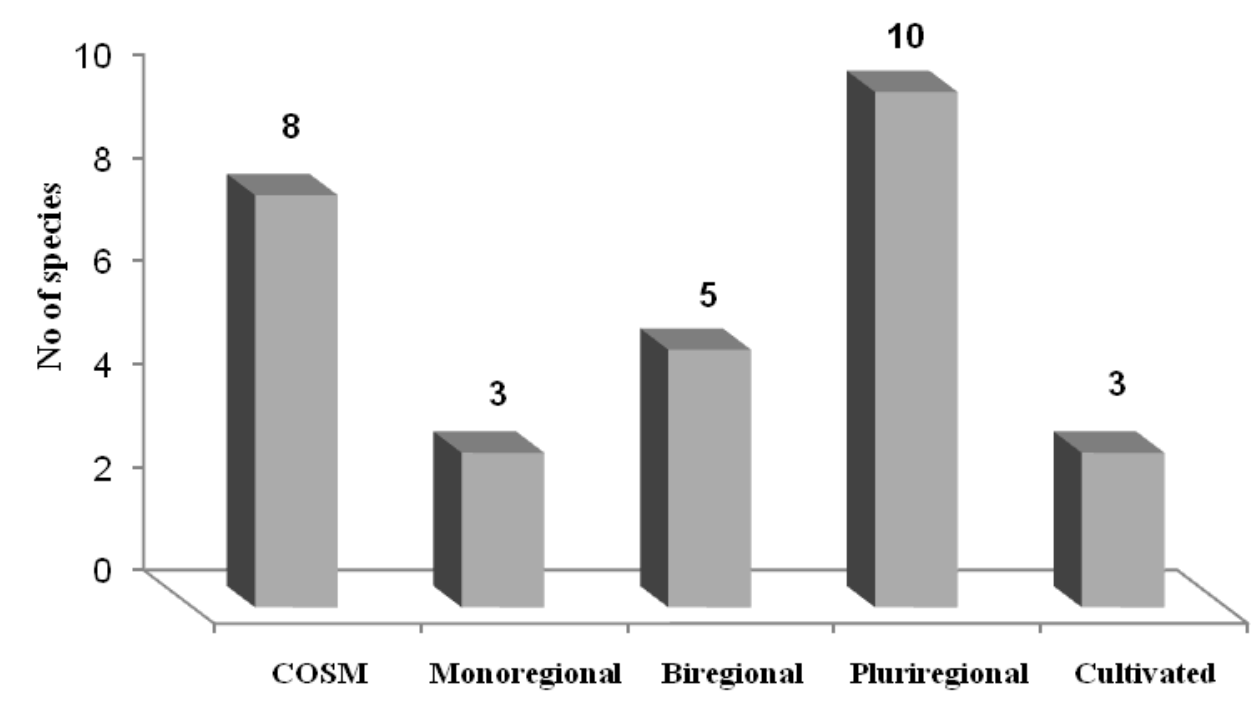

Fig 3. Floristic category of the recorded species associated with wheat crop.

\subsubsection{Vegetation Analysis}

The application of TWINSPAN on the cover estimates of 29 associated species recorded in the 60 sampled stands of wheat, led to the recognition of 8 vegetation groups (Fig. 4). These groups showed a reasonable segregation along the ordination plane axes 1 and 2 of 
DECORANA (Fig. 5). The vegetation groups are named after the first dominant species (the species that have the highest presence percentage and / or the highest cover) associated with T. aestivum. The presence of wheat was $100 \%$ in all vegetation groups, while cover varied from one group to another. The description of these vegetation groups was indicated in Table (2) as follows:

Convolvulus arvensis (VG A): It includes two stands and 16 species. In this group Triticum aestivum was represented by $77.5 \%$ cover, while $C$. arvensis was represented by $3.0 \%$ cover and $100 \%$ presence. The associated species include A. arvensis, Sonchusoleraceous, B. vulgaris, C. murale and Polypogon monspliensis.

Malva parviflora (VG B): It includes six stands and 21 species. T. aestivum was represented by $71.7 \%$ cover, while $M$. parviflora was represented by $2.3 \%$ cover and $100 \%$ presence. The common associated species include P. monspliensis, C. murale, $M$. polymorpha, C. pursa-pastoris and Rumex dentatus.

Polypogon monspliensis (VG C): It includes six stands and 19 species. In this group T. aestivum was represented by $76.7 \%$ cover, while $P$. monspliensis was represented by $1.1 \%$ cover and $100 \%$ presence. The associated species include Poaannua, Raphanus sativus, $R$. dentatus, C. arvensis and S. oleraceous.

Capsellapursa-pastoris (VG D): It includes 23 stands and 23 species. In this group, $T$. aestivum was represented by $72.4 \%$ cover, while $C$. pursa-pastoris was represented by $0.8 \%$ cover and $87.5 \%$ presence. A. fatua, P. monspliensis, $P$. annua, C. arvensis and $M$. polymorpha are the common associated species.

Euphorbia peplus (VG E): It comprises 6 stands and 17 species. T. aestivum was represented by $75.8 \%$ cover, while E. peplus was represented by $2.2 \%$ cover and $100 \%$ presence. The associated species include Pisum sativum, C. murale, C. niloticus, B. vulgaris and Silrene rubella.

Chenopodium murale (VG F): This group comprises 5 stands and 15 species. In this group, T. aestivum was represented by $63.0 \%$ cover, while C. murale was represented by $7.0 \%$ cover and $60.0 \%$ presence. The associated species include $C$. pursa-pastoris, C. endivia, C. arvensis, E. peplus and B. vulgaris.

Sonchus oleraceous (VG G): It includes 9 stands and 19 species. In this group, T. aestivum was represented by $67.8 \%$ cover, while S. oleraceous was represented by $0.9 \%$ cover and $100 \%$ presence. C. murale, C. pursa-pastoris, M. parviflora, C. niloticus and B. vulgaris are the common associated species.

Beta vulgaris (VG H): This group includes 3 stands and 15 species. It was found that, T. aestivum had $70.0 \%$ cover, while B. vulgaris had $0.7 \%$ cover and $100 \%$ presence. The 
associated species comprise M. parviflora, C. pursa-pastoris, U. urens, R. sativus and $C$. rotundus.

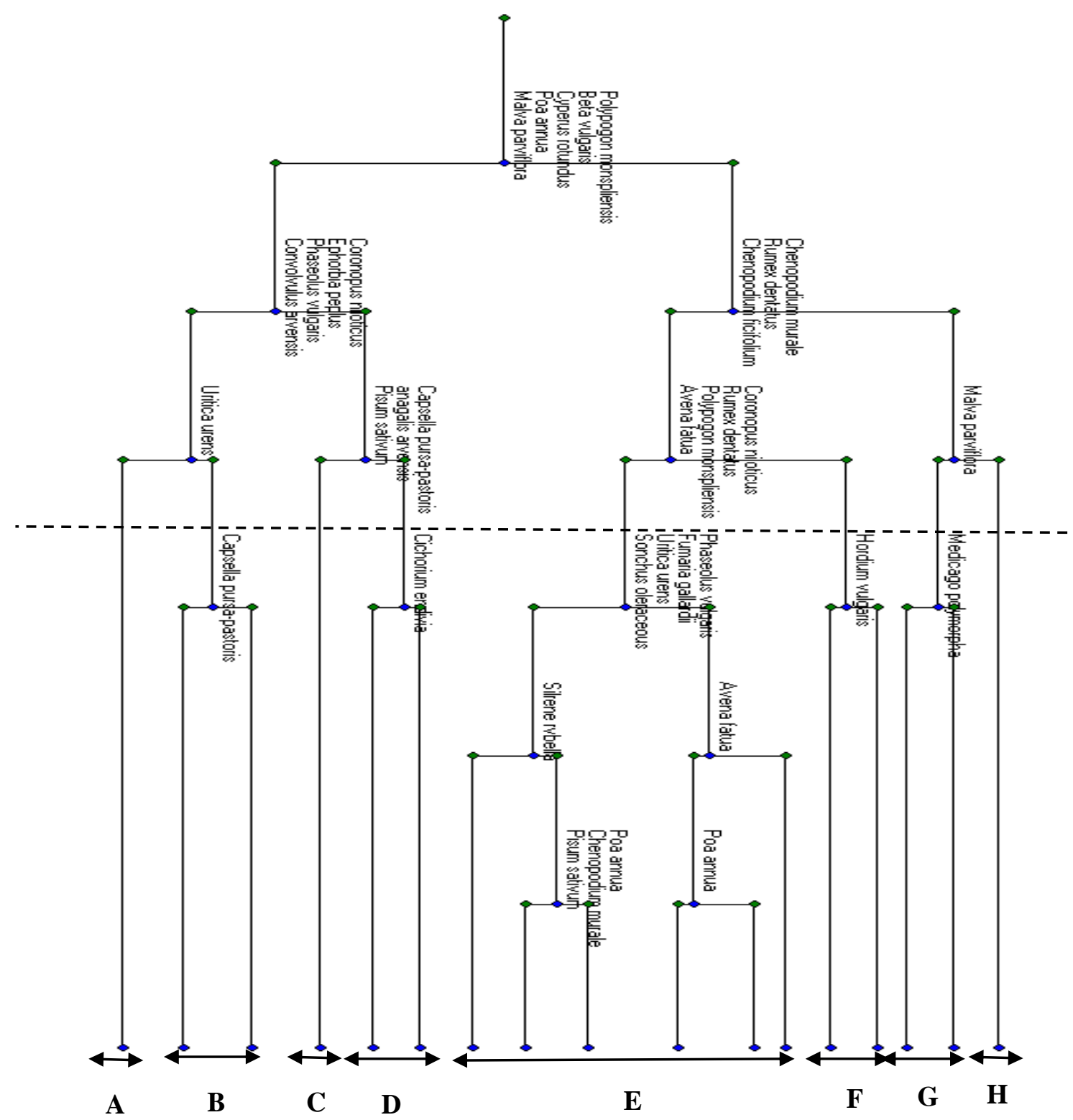

Fig. 4. The dendrogram resulting from the application of TWINSPAN on the 60 sampled stands. The names of these groups are: A: Convolvulus arvensis, B: Malva parviflora, C: Polypogon monspliensis, D: Capsella pursa-pastoris,E: Euphorbia peplus,F: Chenopodium murale, G: Sonchus oleraceous, and $\mathbf{H}$ : Beta vulgaris. 


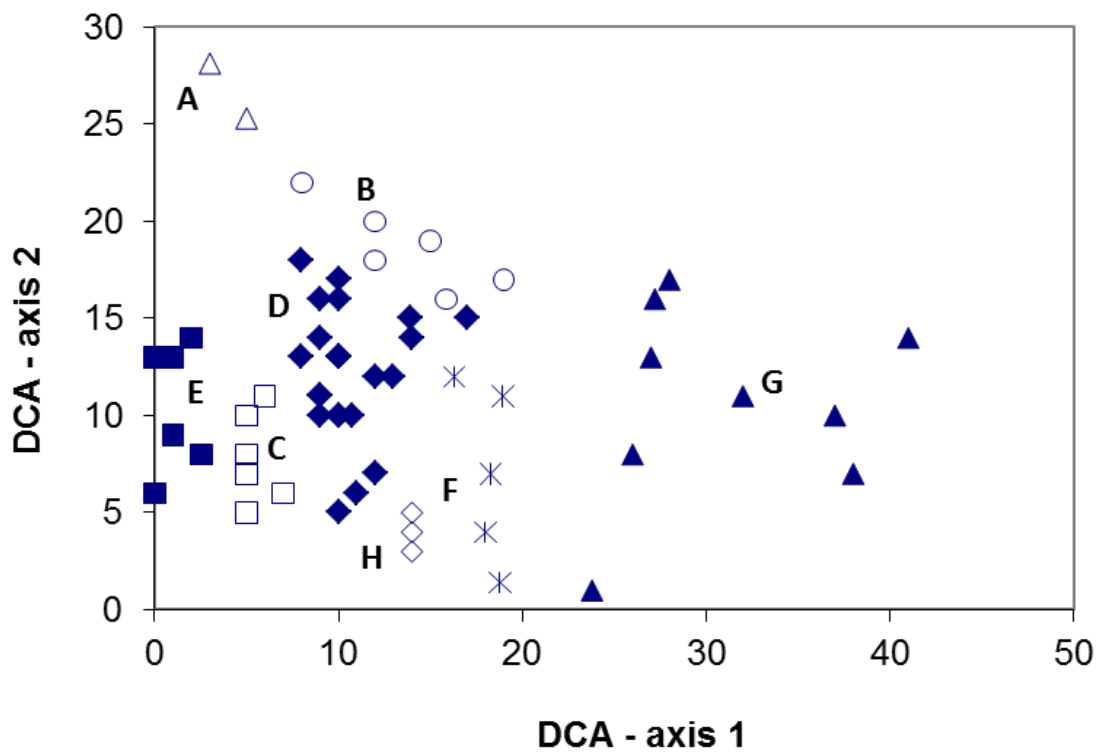

Fig. 5. DCA ordination of the 8 vegetation groups identified after the application of TWINSPAN on the 60 sampled stands. The names of these groups are: A: Convolvulus arvensis, B: Malva parviflora, C: Polypogon monspliensis, D: Capsella pursa-pastoris,E: Euphorbia peplus, F: Chenopodium murale, G: Sonchus oleraceous, and $\mathbf{H}$ : Beta vulgaris.

\subsubsection{Diversity of the plant communities}

The total number of species recorded in the 8 vegetation groups, identified according to TWINSPAN classification technique, varied from 15 species in C. murale and B. vulgaris groups (VG F and $\mathrm{H}$ ) to 23 species in C. pursa-pastoris group (VG D) (Table. 3). M. parviflora group (VG B) had the highest values of species richness (14.3 species/stand) and relative concentration of dominance (17.4), while VG F had the lowest values of species richness (7.6 species/stand), relative evenness (2.5) and relative concentration of dominance ( 11.4). Moreover, the highest value of relative evenness (2.9) was recorded in VG B and D, while the highest species turnover (2.2) was recorded in VG D (Table. 3).

\subsection{Discussion}

Many grassy and broadleaf weeds are associated with wheat crop, the occurrence of which may depend upon many factors such as location, soil fertility, management etc. (Shah, 2013). The weeds of the cultivated lands of Egypt are mainly short-lived (annuals and biennials) herbs. The main difference in weed composition is between winter and summer crops (Galal, 2001). In the present study, twenty nine weed were recorded as the common associated species of wheat. However, Galal (2001) recorded 35 species associated with wheat crop in Giza area, while Shaltout and El Fahar (1991) recorded 69 species in the Nile Delta. 
Table 2. Average cover $(\mathrm{C})$ and presence $(\mathrm{P})$ of the recorded species associated with wheat in the eight vegetation groups resulted from TWINSPAN

\begin{tabular}{|c|c|c|c|c|c|c|c|c|c|c|c|c|c|c|c|c|}
\hline \multirow{3}{*}{ Species } & \multicolumn{16}{|c|}{ Vegetation group } \\
\hline & \multicolumn{2}{|r|}{$\mathbf{A}$} & \multicolumn{2}{|c|}{ B } & \multicolumn{2}{|c|}{$\mathrm{C}$} & \multicolumn{2}{|c|}{ D } & \multicolumn{2}{|c|}{$\mathbf{E}$} & \multicolumn{2}{|c|}{$\mathbf{F}$} & \multicolumn{2}{|r|}{ G } & \multicolumn{2}{|r|}{$\mathbf{H}$} \\
\hline & $\mathrm{C}$ & $\mathbf{P}$ & C & $\mathbf{P}$ & $\mathbf{C}$ & $\mathbf{P}$ & $\mathbf{C}$ & $\mathbf{P}$ & $\mathrm{C}$ & $\mathbf{P}$ & $\mathbf{C}$ & $\mathbf{P}$ & C & $\mathbf{P}$ & $\mathbf{C}$ & $\mathbf{P}$ \\
\hline Triticum aestivum & 77.5 & 100.0 & 71.7 & 100.0 & 76.7 & 100.0 & 72.4 & 100.0 & 75.8 & 100.0 & 63.0 & 100.0 & 67.8 & 100.0 & 70.0 & 100.0 \\
\hline Pisum sativum & & & & & 0.5 & 16.7 & 0.5 & 30.4 & 1.6 & 100.0 & 0.5 & 20.0 & 0.8 & 77.8 & & \\
\hline Medicago polymorpha & & & 1.4 & 66.7 & & & 0.8 & 8.7 & & & & & 1.0 & 33.3 & & \\
\hline Sonchus oleraceous & 0.5 & 100.0 & 0.8 & 83.3 & 0.7 & 50.0 & 0.6 & 60.9 & 0.6 & 66.7 & 0.5 & 20.0 & 0.9 & 100.0 & 0.5 & 33.3 \\
\hline Beta vulgaris & 0.5 & 50.0 & 1.3 & 50.0 & & & 0.5 & 4.3 & 1.1 & 66.7 & 0.8 & 40.0 & 1.2 & 66.7 & 0.7 & 100.0 \\
\hline Chenopodium murale & 0.5 & 100.0 & 2.0 & 100.0 & & & 0.6 & 39.1 & 1.6 & 66.7 & 7.0 & 60.0 & 4.5 & 66.7 & 0.5 & 100.0 \\
\hline Phaseolus vulgaris & & & 0.5 & 33.3 & 0.5 & 50.0 & 0.5 & 65.2 & & & & & 0.5 & 33.3 & 0.5 & 100.0 \\
\hline Malva parviflora & & & 2.3 & 100.0 & 0.5 & 66.7 & 0.5 & 82.6 & & & & & 2.3 & 33.3 & 0.5 & 33.3 \\
\hline Coronopus niloticus & 0.5 & 50.0 & 0.6 & 83.3 & & & 0.7 & 52.2 & 1.3 & 66.7 & 0.5 & 20.0 & 1.4 & 77.8 & 0.5 & 100.0 \\
\hline Capsella pursa-pastoris & 0.5 & 50.0 & 1.4 & 83.3 & 0.5 & 50.0 & 0.8 & 87.0 & 0.7 & 100.0 & 4.0 & 80.0 & 2.6 & 44.4 & 1.3 & 100.0 \\
\hline Fumaria gallardii & & & & & 0.5 & 16.7 & 0.5 & 47.8 & 0.5 & 16.7 & 0.5 & 20.0 & & & 0.5 & 66.7 \\
\hline Raphanus sativus & & & & & 1.0 & 16.7 & 0.5 & 4.3 & 0.5 & 16.7 & 0.5 & 40.0 & 0.8 & 66.7 & 0.8 & 66.7 \\
\hline Cichorium endivia & & & & & 0.5 & 16.7 & 0.5 & 13.0 & 0.5 & 33.3 & 1.5 & 40.0 & & & & \\
\hline Convolvulus arvensis & 3.0 & 100.0 & 0.8 & 83.3 & 0.8 & 50.0 & 0.8 & 43.5 & 0.7 & 83.3 & 1.3 & 80.0 & & & & \\
\hline Uritica urens & & & 0.5 & 16.7 & & & 0.5 & 30.4 & 0.5 & 16.7 & 0.5 & 40.0 & & & 0.8 & 100.0 \\
\hline Euphorbia peplus & & & 0.7 & 50.0 & 0.5 & 50.0 & 0.5 & 82.6 & 2.2 & 100.0 & 1.2 & 60.0 & 1.0 & 33.3 & & \\
\hline Anagalis arvensis & 1.3 & 100.0 & 0.5 & 16.7 & 0.5 & 16.7 & 0.7 & 26.1 & 1.1 & 66.7 & & & 0.5 & 11.1 & & \\
\hline Rumex dentatus & 0.5 & 100.0 & 1.3 & 100.0 & 0.8 & 66.7 & & & & & & & 0.5 & 22.2 & & \\
\hline Cyperus rotundus & & & 0.8 & 33.3 & 0.6 & 100.0 & 0.7 & 47.8 & & & & & & & 0.5 & 33.3 \\
\hline Poa апnиа & 0.5 & 50.0 & 1.1 & 66.7 & 1.8 & 50.0 & 0.8 & 73.9 & 0.5 & 16.7 & & & 0.5 & 11.1 & & \\
\hline Silrene rvbella & 0.5 & 50.0 & & & & & 0.5 & 13.0 & 1.2 & 50.0 & & & & & & \\
\hline Avena fatua & 0.5 & 50.0 & 0.8 & 66.7 & 0.5 & 100.0 & 1.8 & 8.7 & & & & & & & & \\
\hline Solanum nigrum & 0.5 & 50.0 & & & & & 0.5 & 4.3 & 0.5 & 16.7 & & & & & & \\
\hline Ranunculus sceleratus & & & 0.5 & 16.7 & & & & & & & & & 0.5 & 22.2 & & \\
\hline Chenopodium ficifolium & 0.5 & 50.0 & 0.7 & 83.3 & & & & & & & & & 0.5 & 11.1 & 0.5 & 33.3 \\
\hline Amaranthus hybridus & 0.5 & 50.0 & 0.5 & 16.7 & 0.5 & 16.7 & & & & & & & 0.5 & 11.1 & 0.5 & 66.7 \\
\hline Polypogon monspliensis & 0.5 & 50.0 & 2.0 & 83.3 & 1.1 & 100.0 & 1.1 & 21.7 & & & & & & & & \\
\hline Hordium vulgaris & & & & & 0.5 & 33.3 & & & & & & & & & & \\
\hline Brassica turnifortii & & & & & & & & & & & 0.5 & 20.0 & & & & \\
\hline Trifolium alexandrinum & & & & & & & & & & & 0.5 & 20.0 & 0.8 & 44.4 & 0.5 & 33.3 \\
\hline
\end{tabular}

Table 3. Diversity indices of the 8 vegetation groups produced from TWINSPAN. Maximum and minimum values are underlined

\begin{tabular}{|l|c|c|c|c|c|c|c|c|}
\hline \multirow{2}{*}{ Diversity index } & \multicolumn{10}{|c|}{ Vegetation group } \\
\cline { 2 - 9 } & A & B & C & D & E & F & G & H \\
\hline Number of species & 16.0 & 21.0 & 19.0 & $\underline{23.0}$ & 17.0 & $\underline{15.0}$ & 19.0 & $\underline{15.0}$ \\
Species richness & 12.0 & $\underline{14.3}$ & 10.7 & 10.5 & 10.8 & $\underline{7.6}$ & 9.7 & 11.7 \\
Species turnover & $\underline{1.3}$ & 1.5 & 1.8 & $\underline{2.2}$ & 1.6 & 2.0 & 2.0 & $\underline{1.3}$ \\
$\begin{array}{l}\text { Relative evenness } \\
\begin{array}{l}\text { Relative concentration } \\
\text { of dominance }\end{array}\end{array}$ & 2.7 & $\underline{2.9}$ & $\underline{1.8}$ & $\underline{2.9}$ & 2.7 & 2.5 & 2.7 & 2.6 \\
\end{tabular}


In the present study, A. arvensis, A. fatua, C. arvensis, $P$. annua and P. monspliensis were the common associated species in wheat crop. This result coincided with those of Galal (2001) in Giza, and Shaltout and El Fahar (1991) and Abouziena et al. (2008) in Nile Delta. Moustafa (1996) stated that the lowest number of species associated with wheat may be attributed to human impact on agriculture and its different process in addition to climatic variation.

Worldwide, Begum et al. (2003) reported 73 weed species in wheat crop in Bangladesh, among them, Chenopodium album, D. sanguinalis and C. dactylon had higher relative abundance values as were recorded in the present study. Similarly, Aslam et al. (1989) stated that Phalaris minor and C. album were the major problematic weeds of wheat in Pakistan. In addition, Hobbs (1990), Dwivedi et al. (1996) and Mishra (2014) reported that, A. fatua, C. dactylon and A. arvensis are the major weeds of wheat in India. Moreover, Nanda and Patro (1996) recorded 20 weed species associated with wheat crop at Orissa, India.

Poaceae included the most dominant plants associated with wheat crop, followed by Cruciferae and Fabaceae, Chenopodiaceae and Asteraceae. These families constitute the bulk of the flora of the study area in accordance with Al-Sodany (1992) in various habitats in north Nile Delta, Speringuel et al. (1991) in the Nile Valley (Upper Egypt), and Khedr et al. (1998) in the north western part of Nile Delta.

Life form spectra provide information that may help in assessing the response of vegetation to variations in environmental factors (Galal, 2005). Therophytes were the dominant life form among the life forms of the recorded species associated with wheat, followed by geophytes-helophytes, chamaephytes and hemicryptophytes. According to Galal (2001), therophytes are the main life forms and most of them are weed species characteristic to the cultivated lands, coinciding with Hassib (1951) on the Egyptian flora. Heneidy and Bidak (2001) pointed out that the dominance of therophytes over the other life forms seems to be a response to the hot-dry climate, topographic variation and biotic influence. In the present study, 26 species, recorded in wheat crop, were annuals. Gomaa (2012) attributed the high contribution of annuals to their short life cycle that enables them to resist the instability of the agro-ecosystem. Annuals are generally characterized by high allocation of resources to the reproductive organs and the production of flowers early in their life-span to ensure some seed production even in a year when the growing season is cut short (Sans and Masalles, 1995). However, Marshall (1989) demonstrated that most perennial species are not adapted to successful establishment in arable crops. 
The spectrum of the global distribution of the recorded species associated with wheat crop indicated that pluri-regional taxa were the dominant elements in wheat, followed by cosmopolitans, bi-regionals and monoregional elements. According to Mashaly (1987), 50\% of the species in the Deltaic sector are Mediterranean taxa, 32\% are pluri-regionals and $8 \%$ are Saharo-Sindian elements. Most of the recorded species were Mediterranean taxa; however presence of phytogeographical elements other than Mediterranean, is believed to be a reflection of intense climatic changes and/or the degradation of the Mediterranean ecosystem which facilitated the invasion of some elements from the adjacent regions (Mashaly, 1987; Madi et al., 2002).

In Egypt, phytosociological studies on weeds along the Nile valley are still limited. In fact, most of the studies that carried out on weed communities are mostly floristic (Galal, 2001). Phytosociologists used ordination techniques to simplify distribution patterns along the gradients of environmental variables (Spink, 1992). The classification of vegetation associated with wheat crop using TWINSPAN analysis, led to identify 8 vegetation groups. $C$. arvensis is a common community associated with wheat. This classification may indicate the significant effects of crop sowing type, management practices and monthly variation on the weed community composition and structure. The effect of crop may be indirect. For example, fertilization regimes, soil management practices, application of herbicides and weed management may vary depending on the crop type, and these factors influence weed community composition (Gomaa, 2012).

The vegetation groups, resulted from TWINSPAN classification, are clearly distinguished by the first two DCA axes. Thus, the DCA analysis also strengthens the importance of crop and season for the formation of weed community. These results agreed with those of El-Demerdash et al. (1997), Andreasen and Skovgaard (2009), Pinke et al. (2010) and Gomaa (2012), who pointed out that season, soil characteristics, management practices and crop type, contribute to the composition of weed community.

One of the dominant weed communities associated with wheat crop was $C$. murale, which was reported by Shaltout and El-Halawany (1992) and Gomaa (2012) to dominate some weed communities of date palm orchards in eastern Saudi Arabia. In addition, it also dominated weed communities of winter crops in Egypt (Hegazy et al., 2004). Moreover, $C$. arvensis community, dominated wheat crop, was recorded by Shaltout and El-Halawany (1992) as dominant weeds in eastern Saudi Arabia. It was listed as a co-dominant species in the date palm orchards of Central Saudi Arabia (Gazer, 2011). These two species were listed 
by Chaudhary et al. (1981) among weeds that cause severe infestation in agricultural areas in the central southern and eastern Arabian Peninsula.

Crop type had the most significant influence on species composition although it had a low impact on species richness (Fried et al., 2008). M. parviflora and A. hybridus groups in wheat had the highest values of species richness and diversity. The high species richness may be related to this environmental micro-heterogeneity that promotes diversity (Palmer and Maurer, 1997). The variations in species richness, diversity and evenness among the different community types may be attributed to differences in soil characteristics, substrate discontinuities and the allelopathic effects of one or more invasive species depending on their relative dominance among other associated species (Shehata and Galal, 2015). Moreover, the difference in field management practices may also be a factor that explains differences in weed species richness (Gomaa, 2012). Although weeds are unwanted plants, increased their diversity may have other indirect beneficial effects on agro-ecosystems. For example, increased vegetation diversity can lead to suppression of pests via 'top-down' enhancement of natural enemy populations or by resource concentration and other 'bottom-up' effects acting directly on pests (Shehata and Galal, 2015).

It was clear that species richness in wheat was lower than that recorded in orchards by Gomaa (2012). The low species richness of the study crop compared with orchards may be attributed to the fact that the land of field crops is generally plowed each season before the sowing of crops, a practice that reduces the richness of weeds compared to the orchards that are rarely plowed (Gomaa, 2012). The present study showed that at this local scale, weed species richness and diversity were enhanced when the local surroundings of the focal field are more heterogeneous. Here, this heterogeneity is not so much linked to the diversity of land use types, but mostly relates to the grain of the landscape, i.e. the number of parcels surrounding the focal field. This partly fits expectations from the mosaic concept, where species number should increase with habitat heterogeneity (Gaba et al., 2010).

\section{Conclusion}

Twenty nine species belonging to 28 genera and 17 families were recorded associated with wheat crop. This considered low figure than that recorded in the previous studies, where as the present study was carried on small scale. Its community types were recorded as common associated plants in wheat. The present study is the keystone for further investigation on the weed function and weed management practices. 


\section{References}

Abouziena, H.F., Sharara Faida A.A. and El-Desoki, E.R. Efficacy of cultivar selectivity and weed control treatments on wheat yield and associated weeds in sandy soils. World J. Agri. Sci., 4(3): 384-389 (2008).

Ahmed, D. A. Current status of the flora and vegetation of Nile Delta Region. M.Sc. Thesis, Fac. Sci., Tanta Univ., Tanta, 321 pp (2003).

Al-Johani N.S., Aytah A.A. and Boutraa T. Allelopathic impact of two weeds, Chenopodium murale and Malva parviflora on growth and photosynthesis of barley (Hordium vulgare). Pak. J. Bot. 44(6): 1865-1872 (2012).

Al-Sodany, Y. M. Vegetation Analysis of the Northern Part of the Nile Delta Region. M. Sc. Thesis, Fac. Sci., Tanta Univ., Tanta, 122 pp (1992).

Andreasen, C. and Skovgaard, I.M. Crop and soil factors of importance for the distribution of plant species on arable fields in Denmark. Agri. Ecosyst. Environ., 133: 61-67 (2009).

Aslam, M., Majid, A., Hobbs, P. R., Hashmi, N. I. and Byerlee, D. Wheat in the RiceWheat Cropping System of the Punjab: A Synthesis of on Farm Research Results 19841988, PARC/CIMMYT Paper No. 89-3, Islamabad, Pakistan (1989).

Bastiaans, L., Kropff, M. J., Goudriaan, J. and Van laar, H.H. Design of weed management systems with a reduced reliance on herbicides poses new challenges and prerequisites for modeling crop-weed interactions. Field Crops Res., 67(2): 161-179 (2000).

Begum, M., Iqbal, M. Z., Rezaul Karim, S. M. and Mamun, A. A. Weed Flora of Wheat, Mustard and Lentil Grown in Old Brahmaputra Flood Plain Soils of Bangladesh, Bangladesh J. Agri. Sci., 30 (1): 129-134 (2003).

Boulos, L. Flora of Egypt Check list, Revised Annotated Edition. Al-Hadara Publishing, Cairo, Egypt (2009).

Buhler, D.D. Weed population responses to weed control practices I. Seed bank, weed populations, and crop yields. Weed Sci., 47: 416-422 (1999).

Chaudhary, S.A., Parker, C. and Kasasian, L. Weeds of central, southern and eastern Arabian Peninsula.Trop. Pest Manage. 27: 181-190 (1981).

Chen X., Tang J., Fang Z. and Shimizu K. Effects of weed communities with various species numbers on soil features in a subtropical orchard ecosystem. Agri. Ecosyst. Environ. 102, 377-388 (2004). 
Devi, C., Rao, K.L. and Raju, D.V.M. The effect of row spacing and nitrogen on yield and quality of early maturing sugarcane cultivars. Indian Sugar, 40(7): 541-544 (1990).

Dwivedi, R.K., Bajpai, R.P., Choudhry, S.K. and Mishra, R.K. Integrated Weed Control in Wheat in Northern Hill Region of Chhattisgarh, Indian J. Weed Sci., 28 (3 \& 4): 189190 (1996).

El-Demerdash, M.A., Hosni, H.A. and Al-Ashri, N. Distribution of the weed communities in the north east Nile Delta, Egypt. Fed. Repert., 108: 219-232 (1997).

El-Hadidi, M. N. and Fayed, A. A. Materials for Excursion Flora of Egypt. Täckholmia, 15: 1-223 (1994-1995).

Fried G., Petit S., Dessaint F. and Reboud X. Arable weed decline in Northern France: Crop edges as refugia for weed conservation? Biol. Cons. 142, 238-243 (2009).

Fried, G., Norton, L.R. and Reboud, X. Environmental and management factors determining weed species composition and diversity in France. Agric. Ecosyst. Environ., 128: 68-76 (2008).

Gaba, S. Chauvela, B., Dessainta, F.,Bretagnolle, V. and Petit, S. Agriculture , Ecosystems and Environment Weed species richness in winter wheat increases with landscape heterogeneity. Agric. Ecosyst. Environ., 138(3-4), pp.318-323 (2010).

Galal, T.M. Flora and vegetation of north lakes of Egypt. Ph. D. These, Helwan University, Helwan, 285 pp (2005).

Galal, T.M. Studies on the River Nile Vegetation in El Kahira El Kobra. MSc. Thesis, Faculty of Science, Helwan University, Cairo, Egypt. 187 pp (2001).

Gazer, M.H. Vegetation composition and floristical diversity in date palm orchards of Central Saudi Arabia. Acta Bot. Hung. 53 (1-2): 111-126 (2011).

Ghersa, C.M. and Martínez-Ghersa, M.A. and Suárez, S.A. Spatial and temporal patterns of weed invasions: implications for weed management and crop yield. In: Proceedings of the Second International Weed Control Congress, Copenhagen, Denmark, 41-47 (1996).

Gomaa, N.H. Composition and diversity of weed communities in Al-Jouf province, northern Saudi Arabia. Saudi J. biol. Sci., 19(3): 369-76 (2012).

Hassib, M. Distribution of plant communities in Egypt. Bull. Fac. Sci., Fouad I Univ., 29: 59261 (1951).

Hegazy, A.K., Fahmy, G.M., Ali, M.I. and Gomaa, N.H. Vegetation diversity in natural and agro-ecosystems of arid lands. Community Ecol., 5: 163-176 (2004).

Heneidy, S.Z. and Bidak, L.M. Multipurpose plant species in Bisha, Asir Region, Southwestern Saudi Arabia. J. Biol. Sci., 7 (6): 1010-1023 (2001). 
Hill, M. O. TWINSPAN: A FORTRAN Program for Arranging Multivariate data in an Ordered To-way Table by Classification of the Individual and Attributes. Cornell Univ., Ithaca, New York, 90 pp (1979a).

Hill, M. O. DECORANA: AFORTRAN Program for Detrended Correspondence Analysis and Reciprocal Averaging: Cornell Univ., Ithaca, New York, 52 pp (1979b).

Hobbs, P.R., Beniwal, S.P.S. and Girr, G.S. Reduced and zero tillage options for establishment of wheat after rice in south Asia. Proceeding of the 5th International Wheat Conference, Turkey. P. 455-465 (1998).

Johnson, D.E., Wopereis, M.C.S., Mbodj, D., Diallo, S., Powers, S. and Haefele, S.M. Timing of weed management and yield losses due to weeds in irrigated rice in the Sahel. Field Crops Res., 85: 31-42 (2004).

Khedr, A.A. and Hegazy, A.K. Ecology of the rampant weed Nymphaea lotus L. Willdenow in natural and ricefield habitats of the Nile Delta. Egypt. Hydrobiol. 386: 119-129 (1998).

Kulkarni, S.D, Acharya, R., Rajurkar, N.S. and Reddy, A.V.R. Evaluation of bioaccessibility of some essential elements from wheatgrass (Triticum aestivum L.) by in vitro digestion method. Food Chem., 103: 681-688 (2007).

Madi, M. I.; Shaltout, K. H. and Sharaf El-Din, A. Flora of the coastal sand dunes of Gaza strip, Palastine. Proc. 2 nd Conf. Biol. Sci., Tanta Univ. 2: 64-78 (2002).

Magurran, A.E. Ecological Diversity and its Measurements. Croom. Helm., London, 179 pp (1988).

Marshall, E.J.P. Distribution patterns of plants associated with arable field edges. J. Appl. Ecol., 26: 247- 257 (1989).

Mashaly, I. A. Ecological and floristic studies of Dakahlia-Damietta Region. Ph.D. Thesis, Fac. Sci., Mansoura Univ., Mansoura, 282 pp (1987).

Millennium Ecosystem Assessment Ecosystems and human wellbeing: biodiversity synthesis. Washington, DC, World Resources Institute (2005).

Mishra, A. Effect of winter maize-based intercropping systems on maize yield, associated weeds and economic efficiency. Comunicata Scientiae 5(2): 110-117 (2014).

Moustafa, M.A., Boersma, L. and Kronstad, W. E. Response of four spring wheat cultivars to drought stress. Crop Science, 36, 982-986 (1996).

Muller-Dombois, D. and Ellenberg, H. Aims and methods of vegetation ecology. John Wiley and Sons, New York (1974). 
Nanda, S. S. and Patro, G. K. Effect of weed management practices, row spacing and fertilizer levels on growth and yield of wheat, Indian J. Weed Sci., 28 (1 \& 2): 67-69 (1996).

Palmer, M.W. and Maurer, T.A. Does diversity beget diversity? A case study of crops and weeds. J. Veg. Sci. 8: 235-240 (1997).

Petit, S., Boursault, A., Le Guilloux, M., Munier-Jolain, N. and Reboud, X. Weeds in agricultural landscapes: a review. 31(2): 309-317 (2011).

Pielou, E.C. Ecological diversity. A Willy-Inter-science Publication New York, 165 pp (1975).

Pinke, G., Pa' I, R. and Botta-Duka't, Z. Effects of environmental factors on weed species composition of cereal and stubble fields in western Hungary. Cent. Eur. J. Biol., 5 (2): 283-292 (2010).

Radicetti, E., Mancinelli, R. and Campiglia, E. Impact of managing cover crop residues on the fl oristic composition and species diversity of the weed community of pepper crop ( Capsicum annuum L .). Crop Protect., 44: 109-119 (2013).

Raunkiaer, C. Plant Life Forms. Clarendon, Oxford, 104 pp (1937).

Sans, F.X. and Masalles, R.M. Phenological patterns in an arable land weed community related to disturbance. Weed Res., 35: 321-332 (1995).

Shah, P. Weeds associated with tillage, mulching and nitrogen in wheat and their effect on yield : a review. Int. J. Geol. Agri. Environ. Sci., 1(1): 20-25 (2013).

Shaltout, K.H. and El-fahar, R.A. Diversity and phenology of weed communities in the Nile Delta region. J. Veg. Sci., 2: 385-390 (1991).

Shaltout, K.H. and El-Halawany, E.F. Weed communities of date palm orchards in eastern Arabia. Qatar Univ. Sci. J., 12: 105-111 (1992).

Shehata, H.S. and Galal, T.M. Factors affecting the distribution and associated species of Malva parviflora in the Nile Delta, Egypt. Weed Biol. Manage., 15: 42-52 (2015).

Spink, A.J. The ecological strategies of aquatic Ranunculus species. Ph.D. Thesis, Glasgow Univ., Glasgow (1992).

Springuel, I., El-Hadidi, M.N. and Ali, M.M. Vegetation gradient on the shores of Lake Nasser in Egypt. Vegetatio, 94: 15-21 (1991).

Täckholm, V. Student's flora of Egypt. 2nd Edn., Cairo University Press, Egypt.(publ.), Cooperative Printing Company, Beirut, 888 pp (1974).

Uchino, H., Iwama, K., Jitsuyama, Y., Ichiyama, K. and Sugiura, E. Effect of interseeding cover crops and fertilization on weed suppression under an organic and rotational 
cropping system. 1. Stability of weed suppression over years and main crops of potato, maize and soybean. Field Crop Res., 127: 9-16 (2012).

Uchino, H., Iwama, K., Jitsuyama, Y., Yudate, T. and Nakamura, S. Yield losses of soybean and maize by competition with interseeded cover crops and weeds in organicbased cropping systems. Field Crops Res., 113: 342-351 (2009).

Whittaker, G.H. Evolution and measurement of species diversity. Taxon, 21: 231-251 (1972).

Wickens, G. E. The flora of Jebel Marra (Sudan Republic) and its geographic affinities.Kew Bull. Add. Sen. V. HMSO, London, 198 pp (1977).

Zhang F. and Zhang J.T. Research progress of numerical classification and ordination of vegetation in China. J. Shanxi Univ. (Natural Sciences and Education) 23, 278-282 (2000).

Zohary, M. Flora Palaestina. Vol. 1, The Israel Academy of Sciences and Humanities, Jerusalem, 364 pp (1966).

Zohary, M. Flora Palaestina. Vol. 2, The Israel Academy of Sciences and Humanities, Jerusalem, 489 pp (1972). 


\section{الملخص باللغة العربية}

دراسة الغطاء النباتى لمجتمعات الحشائش الرئيسية المصاحبة لمحصول القمح

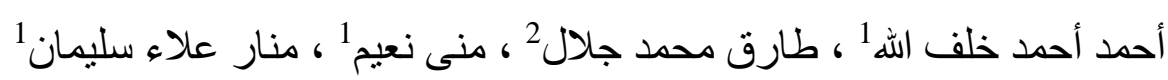

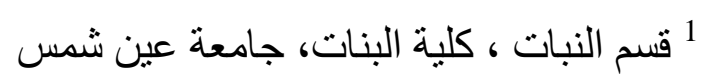

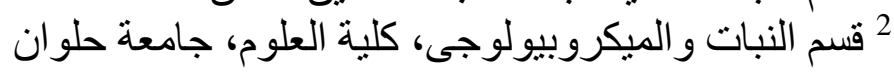

تهاف الدر اسة الحالية الى التعرف على الفلور ا والغطاء النباتي لمحصول القمح و الحشائش الدصاحبة له

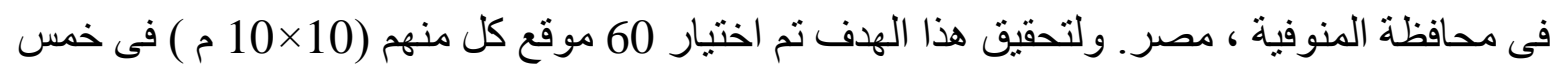

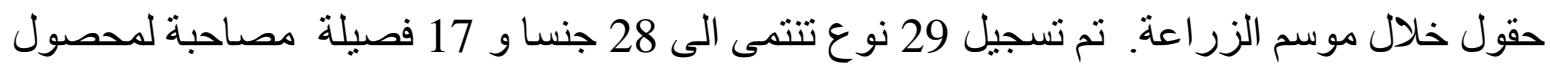

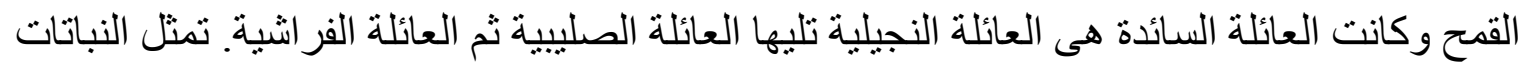

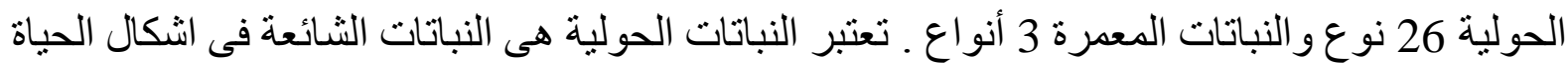

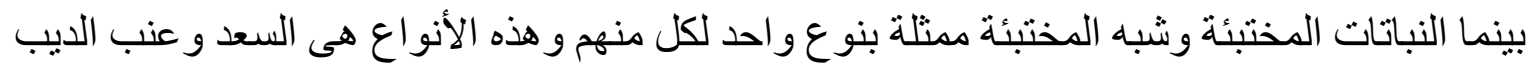

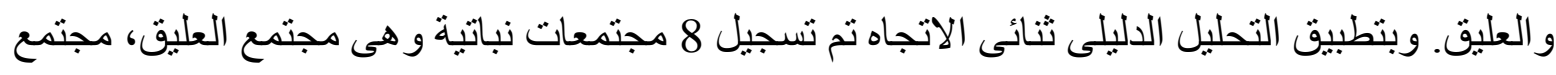

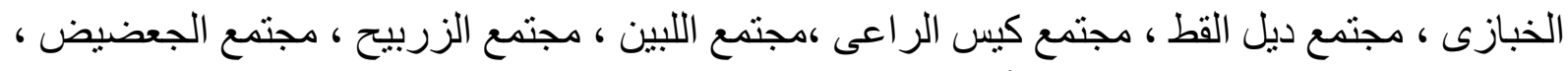

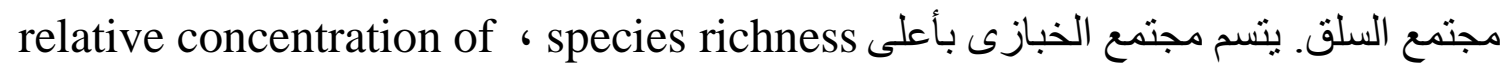

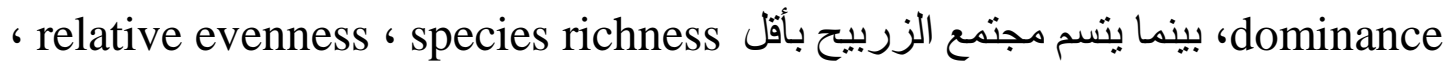
باعلى.relative concentration of dominance - relative evenness بأعلى 